\title{
Evolution of the Earth as an andesite planet: water, plate tectonics, and delamination of anti-continent
}

\author{
Yoshiyuki Tatsumi ${ }^{1,2^{*}}$, Takeshi Sato ${ }^{3}$ and Shuichi Kodaira ${ }^{3}$
}

\begin{abstract}
The Earth is unique in our solar system in having a buoyant, highland-forming continental crust with a differentiated, andesitic composition; thus, it can be referred to as an "andesite planet." Andesitic magmatism is associated with convergent plate margins such as subduction zones, leading to a broad consensus that this setting has been the major site of continental crust formation. However, while andesites are dominant in mature continental arcs, they are subordinate in juvenile oceanic arcs, resulting in a great conflict regarding the creation of the continental crust. We focused on the Izu-Bonin-Mariana arc to assess this problem, as it is a juvenile intra-oceanic arc with a mid-crustal layer that has a seismic velocity identical to that of the bulk continental crust. Petrological modeling of the production of andesitic melts by the mixing of mantle-derived basalt with crust-derived, rhyolite magmas successfully reproduced the crust/mantle structure observed in seismic profiles of the Izu-Bonin-Mariana arc. As a result, we presented a challenging hypothesis: the continent was created in the ocean. One key mechanism that differentiates initial basaltic arc crust to evolved, andesitic continental crust may be the delamination of $\mathrm{SiO}_{2}$-depleted residues of crustal melting, termed "anti-continent," from the arc crust.
\end{abstract}

Keywords: Earth's crust; Continent; Anti-continent; Delamination; Water; Plate tectonics

\section{Correspondence/findings}

\section{Introduction}

Known terrestrial planets possess a common internal structure with a metallic core, a rocky mantle, and an evolved crust, although the presence of two layers in the core, i.e., liquid and solid, is uncertain in terrestrial planets other than the Earth (Fig. 1). Thus, it would seem appropriate to ascribe a fundamentally common mechanism to the formation and evolution of these inner planets. However, current surface features of terrestrial planets are highly variable, suggesting that different tectonic regimes have operated during the evolution of these planets. One such example is topography. The Earth exhibits a bimodal height distribution at the surface (Fig. 1) in contrast to the rather even surface of other terrestrial planets. This unique "lowland vs. highland" topography of the Earth is a consequence of

\footnotetext{
* Correspondence: tatsumi@diamond.kobe-u.ac.jp

'Department of Planetology, Kobe University, Kobe 6567-8501, Japan ${ }^{2}$ Research and Development Center for Ocean Drilling Science, Japan Agency for Marine-Earth Science and Technology, Yokosuka 237-0061, Japan Full list of author information is available at the end of the article
}

the distribution of continental and oceanic crust on the fluidal and denser mantle, each with distinct densities and thicknesses that are on average 2700 vs. $2900 \mathrm{~kg} / \mathrm{m}^{3}$ and 40 vs. $6 \mathrm{~km}$, respectively. The contrast in density is due to a difference in their average compositions; the continental crust is intermediate or andesitic, containing 60 wt\% $\mathrm{SiO}_{2}$, whereas the oceanic crust is mafic or basaltic, containing $50 \mathrm{wt} \% \mathrm{SiO}_{2}$ (e.g., Christensen and Mooney 1995; Kelemen 1995; Taylor and McLennan 1995; Rudnick 1995). In contrast, other terrestrial planets are covered with a uniform crust that is broadly mafic in composition (e.g., Taylor and McLennan, 2009). Therefore, it may be appropriate to regard the Earth as unique in our solar system, being the only "water planet," "shore planet," and "andesite planet." In this study, we examined the mechanism of continental crust formation and emphasized the role of the delamination of mafic components in the creation of the evolved, andesitic crust found on the Earth, by analyzing the seismic and petrologic crust-mantle structure of the juvenile Izu-Bonin-Mariana arc.

\section{实}




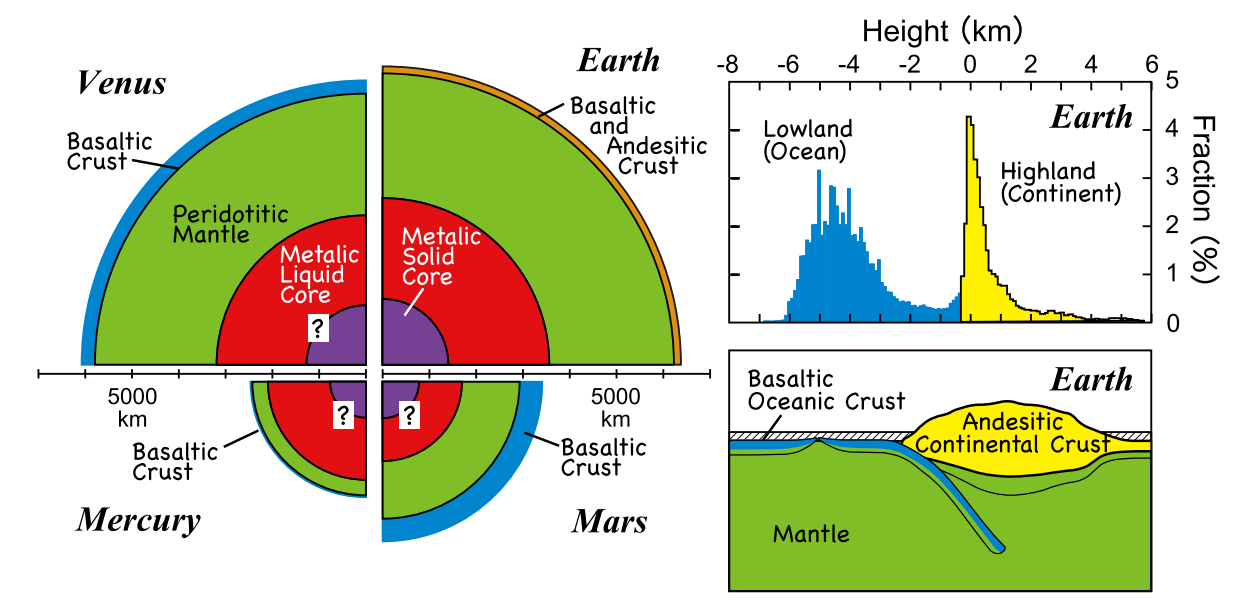

Fig. 1 Inner structures of the terrestrial planets (left) and characteristics of the Earth (right). Although the terrestrial planets show a common layered structure, the Earth is distinct in its bimodal height distribution at its surface, caused by magmatism associated with plate tectonics

\section{Two types of Earth's crusts: a consequence of plate} tectonics

The presence of a high-temperature metallic core, common to all terrestrial planets (Fig. 1) (Aitta, 2012; Smith et al., 2012; Stevenson, 2001), causes convection in the mantle with a high Rayleigh number. Since mantle viscosity strongly depends on temperature (e.g., Karato and $\mathrm{Wu}, 1993)$, the top thermal boundary layer, the lithosphere, is very viscous and stiff. Stagnant lid convection, involving heat transfer by conduction in the upper lid underlain by a convecting mantle, should be the most likely mode of mantle convection and is typical of mantles in other terrestrial planets such as Venus, Mercury, and Mars (e.g., Solomatov, 1995; Schubert et al., 2001), where the entire planetary surface consists of one continuous plate.

The Earth, on the other hand, is unique among the terrestrial planets of the solar system because the lithosphere or lid is broken into multiple tectonic plates that move and founder into the mantle, i.e., the operation of plate tectonics. For such a distinctive regime to exist, stresses associated with mantle convection have to exceed the strength of the rigid lithosphere, which may happen with weakening of the lithosphere. The presence of water is one possible mechanism that reduces the yield strength of the lithosphere and friction on faults (e.g., Moresi and Solomatov, 1998; Valencia et al., 2007; Korenaga 2009). The timing of the onset of plate tectonics is still debated. For example, Stern (2005) suggests the initiation of modern-style plate tectonics at 1 Gya based on the absence of ophiolites and ultra-highpressure metamorphism before that era. Hopkins et al. (2010) considered that zircon dating back to >4.2 Gya may indicate the operation of plate tectonics in the Hadean. On the other hand, there is mounting evidence that both ocean formation and plate tectonics operation took place in the early Archean (3.6-3.9 Ga) (Nutman et al., 2002; Komiya et al., 1999; Shirey et al., 2008). Once plate tectonics started operating, magmatism occurred in two different tectonic settings: at divergent plate boundaries such as mid-ocean ridges and continental rifts, and at convergent plate boundaries such as arc-trench systems and collision zones. The two distinct types of crust that characterize the Earth are believed to have been created at these two different plate boundaries.

The basaltic composition of Earth's oceanic crust has been inferred from the analyses of rocks sampled from both oceanic crust and their analogs-ophiolites that once formed the ocean floor before being obducted onto the continent (e.g., Dewey and Bird, 1971; Coleman, 1977; Dilek and Furnes 2011). It has been established that the oceanic crust forms the top part of the oceanic plate and is created at mid-ocean ridges.

The continental crust is too thick to sample directly in its entirety. Therefore, its composition has been estimated indirectly by comparing the seismic velocity structure of the crust and the measured velocities of various rocks under crustal P-T conditions, in addition to studies of crustal xenoliths. The average P-wave velocity $\left(V_{P}\right)$ of the continental crust is $\sim 6.5 \mathrm{~km} / \mathrm{s}$, suggesting that the bulk continental crust is andesitic in composition (e.g., Christensen and Mooney 1995).

Andesite, the name of which is derived from the Andes Mountains, and its plutonic equivalents such as tonalite and granodiorite represent magmatism in subduction zones where active arcs form because of plate subduction. As a result, the "andesite model" was put forward by Taylor (1967) in which continental crust is created at subduction zones by magmatism. However, it is also now well known that while andesites are predominant in continental arcs with mature continental crust, basalts are the major volcanic products at intra-oceanic 
arcs with a juvenile crust (e.g., Gill, 1981; Ewart, 1982; Tatsumi and Eggins, 1995). This leads to a fundamental problem with the andesite model; it cannot explain the creation of the initial continental crust but only explains the generation of the continental crust under conditions of pre-existing continental crust.
Izu-Bonin-Mariana (IBM) arc: a site of original continental crust formation?

The IBM arc, which extends $2800 \mathrm{~km}$ southward from the Izu Peninsula (Fig. 2), has evolved due to the subduction of the Pacific Plate since $50 \mathrm{Ma}$, accompanied by back-arc rifting from 25 to $15 \mathrm{Ma}$ that separated the

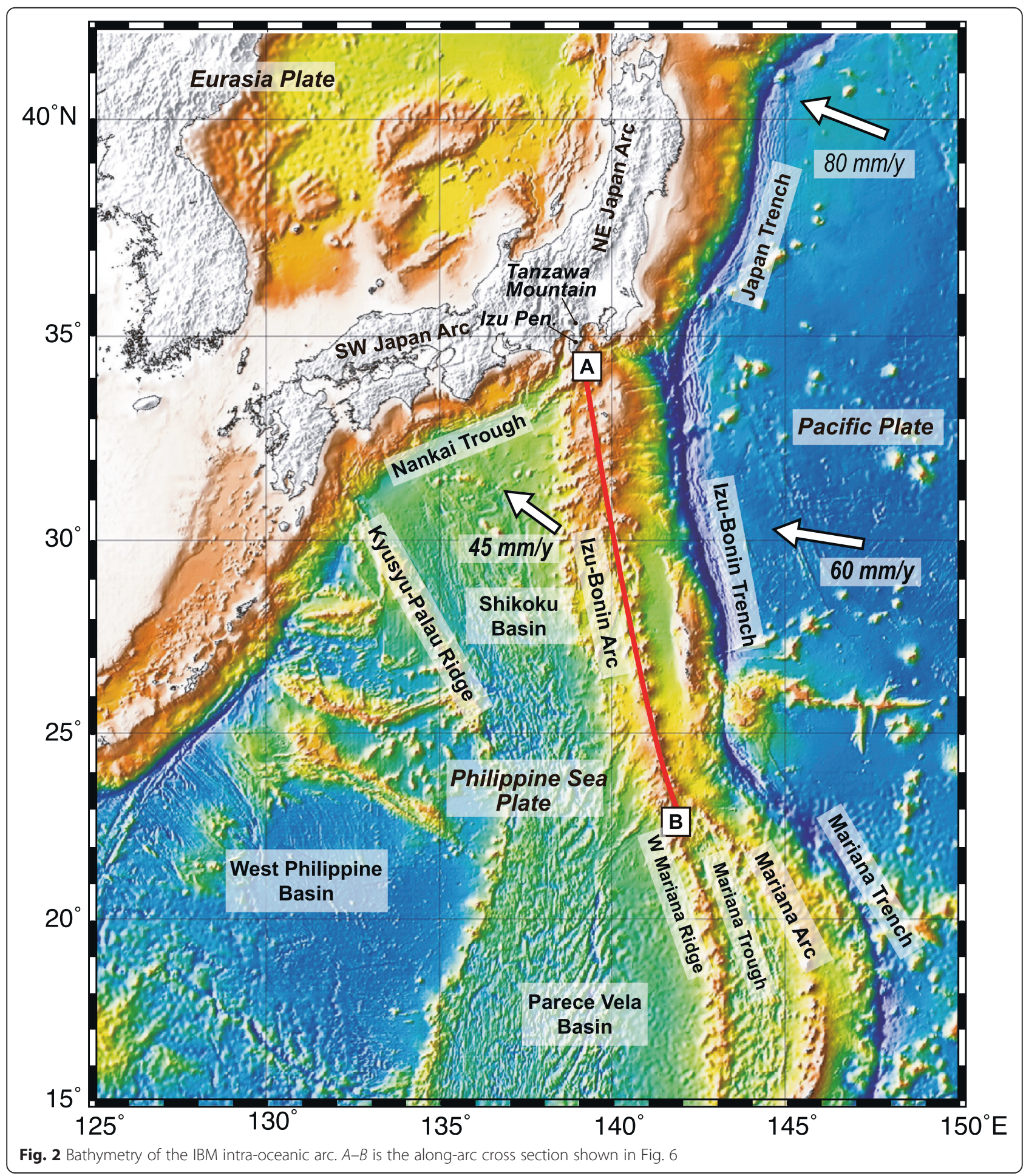


IBM arc from the remnant Kyushu-Palau ridge, creating the Shikoku Basin and Parece Vela Basin (Fig. 2). Backarc rifting was also initiated immediately behind the volcanic front in the central part of the Mariana arc after 2.8 Ma (Taylor 1992; Ishizuka et al. 2002).

One marked structural feature of the IBM arc is the presence of a layer in the middle of the crust with a $V_{P}$ of $6.0-6.8 \mathrm{~km} / \mathrm{s}$, equivalent to that of the average continental crust and typical of intermediate-composition plutonic rocks (Christensen and Mooney, 1995). This middle crust layer is underlain by a lower crust, a low- $V$ uppermost mantle layer, and a normal upper mantle that exhibits a $V_{P}$ of 6.9-7.2, 7.2-7.6, and $>7.8 \mathrm{~km} / \mathrm{s}$, respectively (Fig. 3) (Suyehiro et al., 1996; Takahashi et al., 2007, 2008; Sato et al., 2009). This characteristic layered structure has been confirmed to exist throughout the entire IBM arc (Kodaira et al., 2007a,b; Takahashi et al., 2008; Sato et al., 2009).

The presence of plutonic rocks with andesitic compositions in the IBM middle crust is supported by the recovery of intermediate plutonic rock xenoliths in arc lavas, exposures along the IBM and Kyushu-Palau arc systems (e.g., Sakamoto et al., 1999), the exposure of tonalitic plutons in the Tanzawa Mountains where the IBM arc collides with the Japanese islands (Kawate and Arima, 1998; Tani et al., 2010), and the presence of a 150-km-long felsic melt layer in the Mariana arc (Stern et al., 2013). Furthermore, a middle crust layer with a $V_{P}$ of $6.0-6.8 \mathrm{~km} / \mathrm{s}$ is not unique to the IBM arc; it has also been documented in other intra-oceanic arcs such as the Tonga arc (Crawford et al., 2003) and the Kuriles (Nakanishi et al., 2009). These lines of evidence provide compelling support for a challenging hypothesis; the ingredients for continental crust are created at modern intra-oceanic arcs. Thus, the continents are born in the oceans.

Tatsumi et al. (2008) examined whether petrologic models, including those in which andesitic magma is generated by crustal melting and those in which it is generated by mantle-melting-derived basaltic magma mixing with crust-melting-derived felsic magma, could lead to the genesis of the IBM crust and mantle. They found that the lithologies predicted by these models exhibited a $V_{P}$ consistent with the observed values. However, this modeling was based on a melting regime obtained by compiling the results of melting experiments for a variety of basalts with and without $\mathrm{H}_{2} \mathrm{O}$. Since this study, new constraints on crustal melting and andesitic magma formation in the IBM arc have been provided by Tatsumi and Suzuki (2009), who thoroughly investigated the liquid line of descent for a representative IBM basalt at crustal pressures. Thus, it is important to examine the implications that these latest results have for the lithology and the physical properties of the IBM crust and mantle.

\section{Seismic vs. petrologic structure of the IBM crust and mantle}

Arc evolution model and lithology of crust and mantle

The seismic structure of the sub-IBM arc crust and mantle (Fig. 3) has been petrologically modeled by Tatsumi et al.

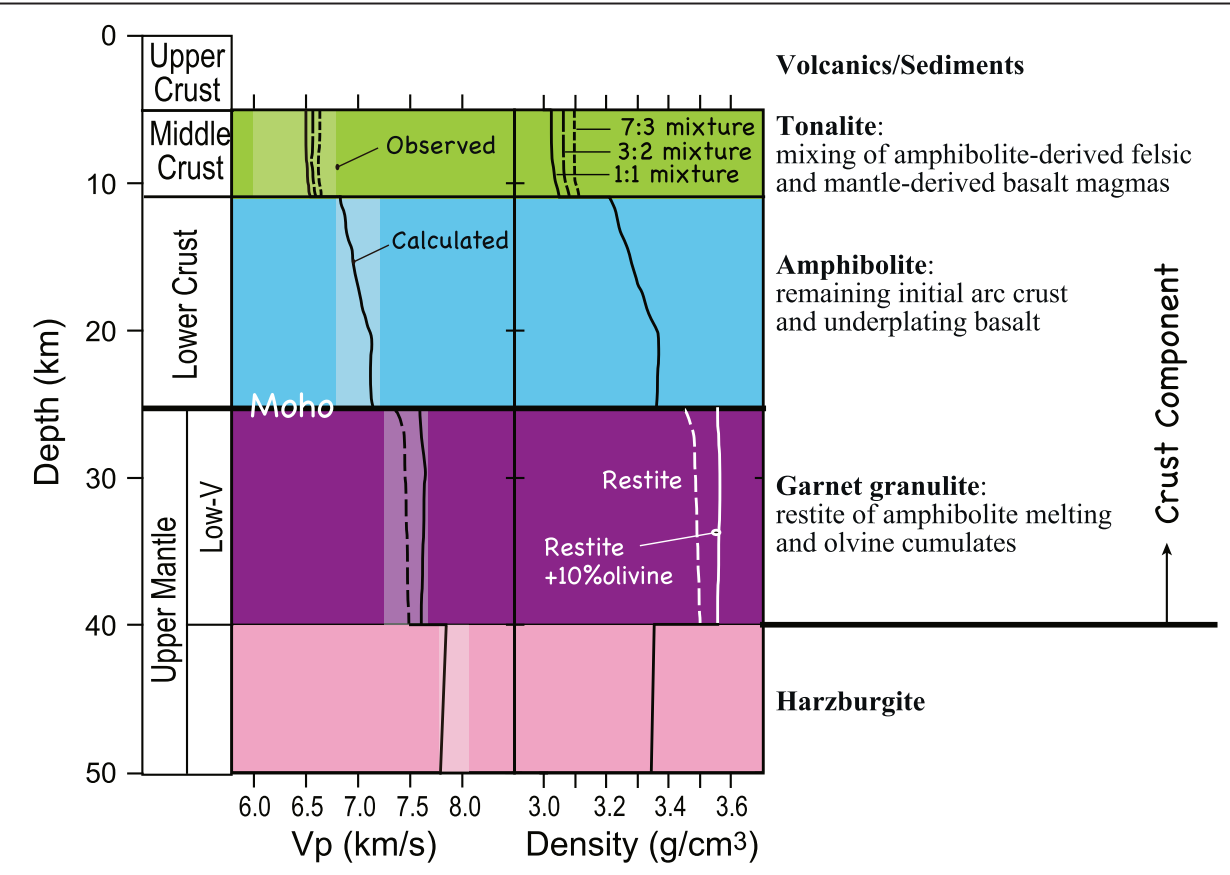

Fig. $3 V_{p}$ structure of the IBM arc and its petrological interpretation. $V_{P}$ and density calculated for the inferred lithologies in the sub-IBM arc crust and mantle are also shown. The calculated $V_{p}$ values (lines) are consistent with the observed $V_{p}$ structure (light area). Note that a density inversion is predicted for the low- $V$ uppermost mantle layer 
(2008, 2014) and is schematically shown in Fig. 4. The compositions of the inferred crust/mantle components used here are listed in Table 1. A representative IBM basalt (basalt in Table 1), which was the initial material used in Tatsumi and Suzuki (2009), was assumed to form the initial arc crust. Although boninite is known to be the lithology for an initial IBM arc (e.g., Ishizuka et al., 2011), it may not be distributed widely, particularly as the intermediate middle crust lithology along the current IBM arc, since this hydrous magma forms amphibole-rich pluton with a $V_{\mathrm{P}}$ greater than observed values (Tatsumi et al., 2008). Successive magmatic underplating caused the partial melting of the initial crust to produce a rhyolitic melt after a $5-10 \%$ partial melting, leaving a restite or a melting residue (the compositions of these components inferred from experiments are listed in Table 1). Mixing of this rhyolite magma with an IBM basalt magma produced andesite magmas (andesites $1-3$ in Table 1 with different mixing ratios), which ascended and solidified to form a middle crust layer. A noteworthy difference in chemistry between the inferred IBM andesite and the average continental crust was a strong depletion in potassium and other incompatible elements in IBM andesites (Table 1). This was due to the production of IBM magmas from depleted peridotite or harzburgite (Tatsumi, 2000), whereas continental crusts may have been created above more fertile peridotites or even enriched mantle/crust (Albarède, 1998; Clift and Vannucchi, 2004).

Since the basalt used in this study as a representative IBM basalt was not a primary magma that was in equilibrium with upper mantle peridotites, olivine cumulates may have formed during magmatic differentiation and would have likely mixed with the restite. The restite with and without $10 \%$ olivine cumulate were then considered to be a possible crust/mantle component. The sub-IBM arc mantle was assumed to consist of harzburgite (Table 1) as it is commonly found as xenoliths in serpentine mud volcanoes in the IBM forearc (Ishii et al., 2000).

In summary, the new modeling suggested that the plutonic equivalent of the mixed andesitic magma was the lithology of the middle crust, the representative IBM basalt was the lithology of the lower crust, the restite with and without olivine cumulates was the lithology of the low- $V$ uppermost mantle, and harzburgite was the lithology of the normal upper mantle (Table 1).

\section{Physical properties of crust and mantle}

Once the chemical compositions of each layer of the subIBM arc crust and mantle were defined, the mineral assemblages and physical properties of these layers were obtained and compared to the observed layered structure.

The amount of $\mathrm{H}_{2} \mathrm{O}$ in magma governs the amount of hydrous phases in a solidified rock and may be a critical control on its physical properties. It was possible to estimate the $\mathrm{H}_{2} \mathrm{O}$ content in magmas by mixing the basalt magma, assumed to contain 0.5 wt $\% \mathrm{H}_{2} \mathrm{O}$ (Tatsumi and Suzuki, 2009), with a rhyolitic magma that was produced by partial melting of the hydrous basalt. Assuming that $\sim 10 \%$ partial melting was required to produce rhyolitic magma, the rhyolite would contain $\sim 5$ wt $\% \mathrm{H}_{2} \mathrm{O}$. An intermediate magma with $\sim 60 \% \mathrm{SiO}_{2}$ produced by a $\sim 3: 2$ mixture of basaltic and rhyolitic magmas would thus contain $\sim 3.2 \mathrm{wt} \% \mathrm{H}_{2} \mathrm{O}$. This value was much higher than the 0.3-0.5 wt $\mathrm{H}_{2} \mathrm{O}$ inferred from the amount of hydrous phases contained in the tonalitic plutonic rocks from the IBM (Tatsumi et al., 2008). With the current data available, however, it was difficult to further constrain the $\mathrm{H}_{2} \mathrm{O}$ content in IBM magmas. Therefore, we tentatively accepted 0.5 wt $\%$ as the $\mathrm{H}_{2} \mathrm{O}$ content of both mixed intermediate and original basaltic magmas.

Assuming the distribution of crust and mantle components outlined above, subsolidus phase equilibria at pressures and temperatures relevant to crust-to-mantle conditions were obtained using the free energy minimization algorithm, Perple_X (Connolly, 1990; 2005), along inferred geothermal gradients. The temperature of the mantle wedge at $70 \mathrm{~km}$ depth was fixed at $1400{ }^{\circ} \mathrm{C}$, the temperature required for arc basalt magma generation (Tatsumi et al., 1983). The surface temperature was fixed at $0{ }^{\circ} \mathrm{C}$ and the temperature at the Moho was set at $750{ }^{\circ} \mathrm{C}$, the solidus temperature of a basaltic rock with $0.5 \mathrm{wt} \% \mathrm{H}_{2} \mathrm{O}$. The subsolidus temperature at the Moho was consistent with the observation that the Moho discontinuity was clearly defined beneath the IBM arc

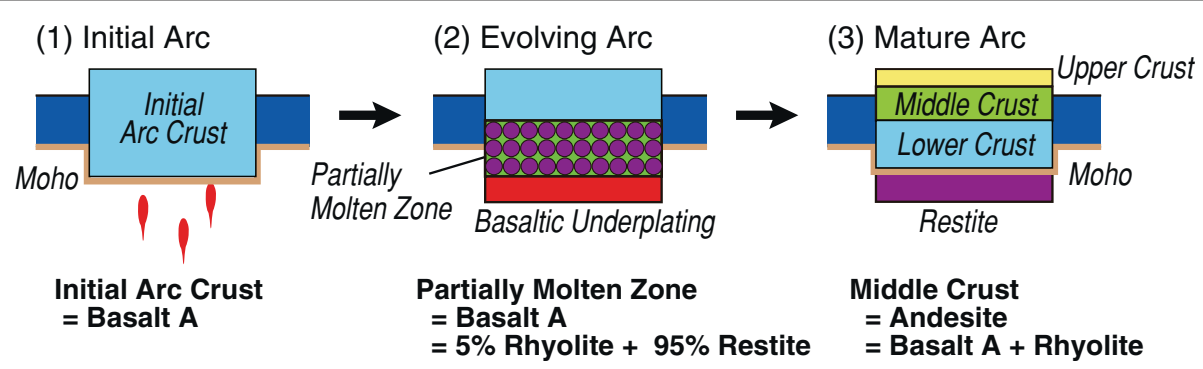

Fig. 4 Schematic diagram showing the model of arc crust evolution from Tatsumi et al. (2008) 
Table 1 Compositions of inferred basaltic and rhyolitic end-member magma and restite

\begin{tabular}{|c|c|c|c|c|c|c|c|c|c|c|c|c|}
\hline & \multicolumn{8}{|c|}{ This study } & \multicolumn{4}{|c|}{ Tatsumi et al. (2008) } \\
\hline & Basalt & Rhyolite & $\begin{array}{l}\text { Andesite } 1 \\
\text { (1:1 mixture) }\end{array}$ & $\begin{array}{l}\text { Andesite } 2 \\
\text { (3:2 mixture) }\end{array}$ & $\begin{array}{l}\text { Andesite } 3 \\
\text { (7:3 mixture) }\end{array}$ & Restite & $\begin{array}{l}\text { Restite + } 10 \% \\
\text { olivine }\end{array}$ & Harzburgite & Basalt & Rhyolite & Restite & Mixed \\
\hline$\overline{\mathrm{SiO}_{2}}$ & 49.40 & 75.00 & 62.20 & 59.64 & 57.08 & 47.76 & 47.00 & 45.40 & 50.00 & 75.00 & 47.22 & 60.00 \\
\hline $\mathrm{TiO}_{2}$ & 0.70 & 0.40 & 0.55 & 0.58 & 0.61 & 0.72 & 0.65 & & 0.80 & 0.30 & 0.86 & 0.60 \\
\hline $\mathrm{Al}_{2} \mathrm{O}_{3}$ & 18.34 & 13.52 & 15.93 & 16.41 & 16.89 & 18.64 & 16.78 & & 19.10 & 14.00 & 19.67 & 17.06 \\
\hline $\mathrm{FeO}^{\mathrm{a}}$ & 11.02 & 2.23 & 6.63 & 7.51 & 8.39 & 11.58 & 11.76 & 5.70 & 10.20 & 2.00 & 11.11 & 6.92 \\
\hline $\mathrm{MgO}$ & 6.41 & 0.68 & 3.55 & 4.12 & 4.69 & 6.78 & 10.75 & 48.90 & 6.00 & 0.20 & 6.64 & 3.68 \\
\hline $\mathrm{CaO}$ & 12.42 & 5.12 & 8.77 & 9.50 & 10.23 & 12.89 & 11.60 & & 12.10 & 3.00 & 13.11 & 8.46 \\
\hline $\mathrm{Na}_{2} \mathrm{O}$ & 1.60 & 1.78 & 1.69 & 1.68 & 1.66 & 1.59 & 1.43 & & 1.60 & 4.50 & 1.28 & 2.76 \\
\hline $\mathrm{K}_{2} \mathrm{O}$ & 0.10 & 1.26 & 0.68 & 0.56 & 0.45 & 0.03 & 0.02 & & 0.20 & 1.00 & 0.11 & 0.52 \\
\hline Total & 100.00 & 100.00 & 100.00 & 100.00 & 100.00 & 100.00 & 100.00 & 100.00 & 100.00 & 100.00 & 100.00 & 100.00 \\
\hline $\mathrm{H}_{2} \mathrm{O}$ & 0.50 & & 0.50 & 0.50 & 0.50 & & & & 0.20 & & & 0.50 \\
\hline
\end{tabular}

${ }^{\mathrm{a}} \mathrm{FeO}$, total $\mathrm{Fe}$ as $\mathrm{FeO}$

Mixing ratio represents basalt/rhyolite

(Kodaira et al., 2007a; Takahashi et al., 2008). On the other hand, the lower crust should be partially molten beneath the region where the arc crust was being created and evolved by the localized heat supply from mantle-derived basalt magmas. This temperature was $\sim 120{ }^{\circ} \mathrm{C}$ lower than the Moho temperature inferred by Tatsumi et al. (2008). This may be due to the greater amount of $\mathrm{H}_{2} \mathrm{O}$ in the basalt composition used in this study ( 0.5 compared to 0.2 $w t \%$ in the earlier study). Oxygen fugacity $\left(f_{\mathrm{O} 2}\right)$ was fixed at an approximate QFM buffer as a stable phase condition, and hence, the physical properties of the lower crust were relatively insensitive to $f_{\mathrm{O} 2}$ (Behn \& Kelemen, 2006). The results of the calculations are shown in Fig. 5 and listed in Table 2.

The resulting mineral assemblages were then used to calculate the physical properties of each layer of the model IBM crust and mantle following the method of Hacker et al. (2003). The calculated seismic velocity and density, together with the observed $V_{P}$ for each layer, are presented in Fig. 3 and Table 2.

One major difference between the calculation results presented here and in earlier efforts was that garnet was ubiquitous both in the lower crust and the uppermost mantle layers in the new results (Fig. 5 and Table 2), but appeared only in the lower portion of the low- $V$ layer in the uppermost mantle in previous results (Tatsumi et al., 2008). This was due to the lower temperature used in this study to keep the lower crust beneath the nonvolcanic region at subsolidus temperatures. The presence of garnet in the IBM crust was apparently inconsistent with the geochemical characteristics of crustderived felsic volcanic rocks that may have been in this arc, suggesting that there was no garnet residue during crustal melting (Tamura et al., 2009). It should be emphasized, however, that the crust-mantle lithology obtained in this study formed under stationary, non-magmatic conditions instead of in higher temperature conditions associated with localized magmatism. Garnet may be replaced by pyroxene and plagioclase at higher temperatures (Tatsumi et al. 2008) when crustal melting takes place, producing felsic magmas with no garnet signatures.

\section{Arc crust evolution via formation and delamination of anti-continent}

Figure 3 shows that the seismic velocities inferred from the petrology of the likely lithologies of the sub-IBM arc crust and mantle provided a $V_{P}$ structure consistent with that observed. This suggested that the sub-IBM arc crust and uppermost mantle may be composed of these lithologies, which have evolved through the processes shown in Fig. 4. In this case, the Moho discontinuity, which defines the boundary between the crust and mantle, may be the boundary between the remaining basaltic, initial arc crust and the restite of crustal melting following the extraction of rhyolitic melts. However, this interpretation requires the crustal component, which is a restite of crustal melting and thus originally forms within the crust (above the Moho), to be transferred to the upper mantle and consequently crossing, and then distributed below the Moho. If so, this confirms the previous suggestion of Tatsumi et al. (2008) that the sub-arc Moho is not a rigid material boundary between crust and mantle materials but is chemically transparent and permeable to crustal components.

It may be reasonable to assume a basaltic composition for the initial arc crust, as magmas produced in the mantle wedge are basaltic in composition (e.g., Tatsumi and Eggins, 1995), except in some unusual tectonic settings where andesitic primary magmas are generated (Tatsumi, 2006) such as during boninite activity at the 


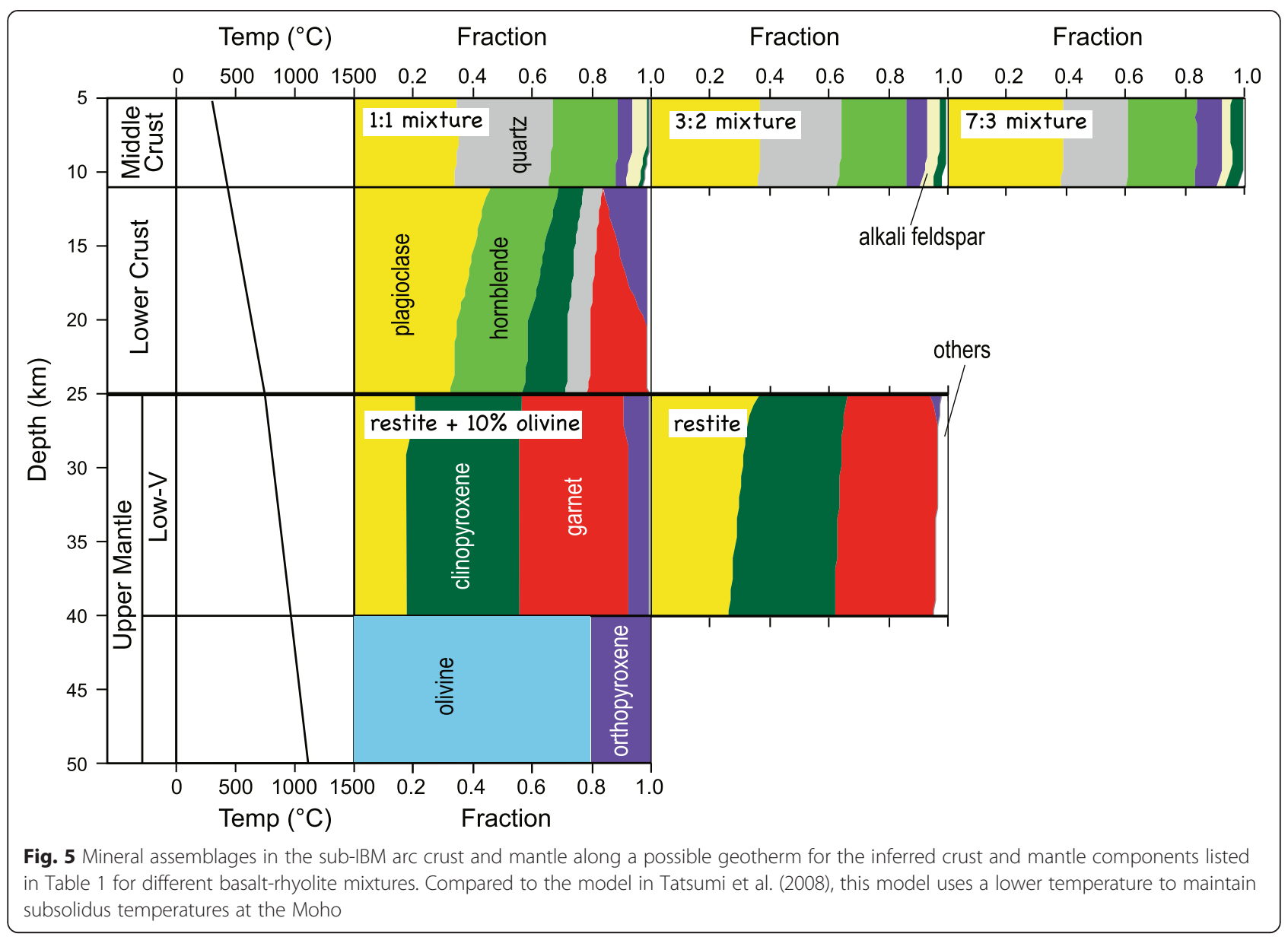

Table 2 Mineral assemblages and physical properties of inferred lithologies for sub-IBM crust and mantle

\begin{tabular}{|c|c|c|c|c|c|c|c|c|c|c|c|c|c|c|c|c|c|c|c|c|c|c|}
\hline \multirow{3}{*}{$\begin{array}{l}\text { Layer } \\
\text { Composition } \\
\text { Depth (km) }\end{array}$} & \multicolumn{9}{|c|}{ Middle crust } & \multirow{2}{*}{\multicolumn{4}{|c|}{$\frac{\text { Lower crust }}{\text { Basalt }}$}} & \multicolumn{9}{|c|}{ Upper mantle } \\
\hline & \multicolumn{3}{|c|}{ 1:1 mixture } & \multicolumn{3}{|c|}{ 3:2 mixture } & \multicolumn{3}{|c|}{$7: 3$ mixture } & & & & & \multicolumn{3}{|c|}{ Restite } & \multicolumn{3}{|c|}{$\begin{array}{l}\text { Restite + } 10 \% \\
\text { olivine }\end{array}$} & \multicolumn{3}{|c|}{ Harzburgite } \\
\hline & 5 & 8.5 & 11 & 5 & 9 & 11 & 5 & 10 & 11 & 11 & 12 & 20.5 & 25 & 25 & 27 & 40 & 25 & 30 & 40 & 40 & 50 & 70 \\
\hline$T\left({ }^{\circ} \mathrm{C}\right)$ & 300 & 380 & 430 & 300 & 390 & 430 & 300 & 410 & 430 & 430 & 450 & 650 & 750 & 750 & 780 & 970 & 750 & 820 & 970 & 970 & 1113 & 1400 \\
\hline uart & 31.7 & 31.6 & 31.9 & 26.9 & 26.8 & 27.0 & 22.0 & 21.8 & 22.0 & 6.2 & 6.3 & 7.2 & 7.3 & 1.5 & 2.6 & 4.1 & & & & & & \\
\hline Plagioclase & 34.8 & 34.8 & 33.6 & 36.8 & 37.0 & 35.9 & 38.8 & 38.8 & 38.1 & 45.3 & 44.5 & 34.4 & 32.2 & 36.6 & 32.2 & 26.0 & 20.4 & 17.1 & 17.1 & & & \\
\hline kali & 4.5 & 4.5 & 4.5 & 3.8 & 3.7 & 3.8 & 3.1 & 3.0 & 3. & 0.7 & 0.7 & 0.7 & 0.7 & 0.2 & 0.2 & 0.2 & 0.2 & 0.2 & 0.2 & & & \\
\hline ornblende & 22.0 & 22.0 & 22.1 & 22.2 & 22.2 & 22.3 & 22.5 & 22.5 & 22.6 & 23.4 & 23.4 & 24.2 & 24.4 & & & & & & & & & \\
\hline Garnet & & 0.4 & 2.3 & & 0.2 & 1.9 & & 0.4 & 1.4 & & 1.4 & 19.3 & 20.5 & 27.1 & 32.1 & 33.5 & 34.6 & 36.8 & 37.0 & & & \\
\hline Olivine & & & & & & & & & & & & & & & & & & & & 80.0 & 80.0 & 80.0 \\
\hline ne & 5.1 & 4.8 & 3.5 & 6.9 & 6.9 & 5.7 & 8.8 & 8.6 & 7.9 & 14.9 & 14.0 & 0.0 & 0.0 & 4.3 & & & 8 & 7.2 & 6.7 & 20.0 & 20.0 & 20.0 \\
\hline Clinopyroxene & 1.3 & 1.3 & 1.4 & 2.6 & 2.6 & 2.7 & 4.1 & 4.1 & 4.2 & 8.7 & 8.9 & 13.3 & 14.4 & 29.8 & 32.3 & 35.6 & 35.6 & 37.7 & 38.5 & & & \\
\hline menite & 0.6 & 0.6 & 0.6 & 0.7 & 0.7 & 0.7 & 0.7 & 0.7 & 0.7 & 0.9 & 0.9 & 0.9 & & & & & & & & & & \\
\hline Rutile & & & & & & & & & & & & & 0.5 & 0.6 & 0.6 & 0.6 & & 0.5 & 0.5 & & & \\
\hline$\rho\left(\mathrm{g} / \mathrm{cm}^{3}\right)$ & 2.92 & 2.93 & 2.95 & 2.96 & 2.96 & 2.98 & 3.00 & 3.00 & 3.01 & 3.11 & 3.12 & 3.27 & 3.26 & 3.35 & 3.38 & 3.40 & 3.46 & 3.46 & 3.46 & 3.25 & 3.24 & 3.20 \\
\hline$V_{p}(\mathrm{~km} / \mathrm{s})$ & 6.50 & 6.51 & 6.54 & 6.57 & 6.56 & 6.59 & 6.63 & 6.63 & 6.65 & 6.82 & 6.85 & 7.13 & 7.14 & 7.33 & 7.45 & 7.48 & 7.60 & 7.64 & 7.62 & 7.86 & 7.81 & 7.51 \\
\hline$V_{\mathrm{S}}(\mathrm{km} / \mathrm{s})$ & 3.82 & 3.81 & 3.82 & 3.82 & 3.80 & 3.82 & 3.82 & 3.80 & 3.81 & 3.80 & 3.82 & 3.98 & 3.99 & 4.06 & 4.12 & 4.14 & 4.23 & 4.25 & 4.23 & 4.49 & 4.44 & 4.22 \\
\hline oisson's ratio & 0.24 & 0.24 & 0.24 & 0.24 & 0.25 & 0.25 & 0.25 & 0.25 & 0.25 & 0.27 & 0.27 & 0.27 & 0.27 & 0.28 & 0.28 & 0.28 & 0.27 & 0.28 & 0.28 & 0.26 & 0.26 & 0.27 \\
\hline
\end{tabular}


very initial stage of IBM evolution (e.g., Meijer, 1980). Therefore, in order to create a continental crust with intermediate compositions in arc settings, the extraction of mafic components from the basaltic arc crust is necessary. A transfer of the restitic crustal component, which has a more mafic composition than the original basaltic composition of the arc crust, to the mantle may provide such a mechanism (see Table 1), causing the arc crust to evolve and possibly form continental crust. Kodaira et al. (2007b) calculated the average seismic velocity excluding the restite layer and suggested that the velocity was close to that of a typical continental crust. The complementary restite may thus be referred to as "anti-continent" (Tatsumi et al., 2008, 2014).

One characteristic seismic feature of the IBM system is the distribution of a seismic reflector at depths of 20$40 \mathrm{~km}$ in the upper mantle, which defines the base of the low- $V$ uppermost mantle layer (Sato et al., 2009), the layer inferred to be the restite or anti-continent. It may thus be interesting to compare the thickness of this low$V$ layer with that predicted by the modeling for the anticontinent.

As a simple model, we assumed that a 3:2 mixing of a rhyolite and a basalt melt containing 75 and $50 \mathrm{wt} \%$ $\mathrm{SiO}_{2}$, respectively, forms a magma with $60 \mathrm{wt} \% \mathrm{SiO}_{2}$, consistent with the lithology of the IBM middle crust. Such a rhyolitic magma can be produced by $\sim 10 \%$ partial melting of the basaltic crust (Tatsumi and Suzuki, 2009). As a result, the thickness of the restite $\left(T_{R}\right)$ was expressed as a function of the thickness of the middle crust $\left(T_{\mathrm{M}}\right): T_{\mathrm{R}}=2 / 5 \times T_{\mathrm{M}} \times 9$. Applying this simple equation to the along-arc seismic structure (Kodaira et al., 2007a; Sato et al., 2009), the distribution of the restite or anti-continent layer was obtained (Fig. 6). The amount of anti-continent required to generate the IBM middle crust resulted in a much thicker layer than that observed for the low- $V$ uppermost mantle layer.

One possible reason for this inconsistency could be the density contrast between the anti-continent and the normal upper mantle (harzburgite). The inferred density of the uppermost mantle, composed of a restite, anticontinent layer, was higher than that for the underlying normal mantle (Fig. 3) due to garnet stabilization in the restite layer (Fig. 5 and Table 2). This would have caused gravitational instability and may have resulted in the "delamination" of the overlying dense anti-continent. This process has been repeatedly emphasized as a possible physical consequence of crustal evolution (England \& Houseman, 1989; Turcotte, 1989; Kay \& Kay, 1993; Jull \& Kelemen, 2001; Tatsumi et al., 2008). Interestingly, highpressure experiments and geochemical modeling have demonstrated that a sinking anti-continent is, in contrast to a subducting oceanic crust, always denser than the surrounding mantle, suggesting that it can penetrate through the upper-lower mantle boundary without stagnation and accumulate at the base of the mantle where it could be recycled in mantle plumes (Tatsumi et al., 2014).

While the IBM arc has been creating a buoyant continental crust, the anti-continent has been simultaneously delaminating from the arc crust. Although the process of the delamination of the anti-continent is unclear, extensive magma generation in the mantle wedge may reduce the viscosity of the upper mantle, triggering the delamination of the dense anti-continent from the arc crust.

\section{Conclusions}

In our solar system, the continents, their highland topography, and the andesitic crust that forms them are

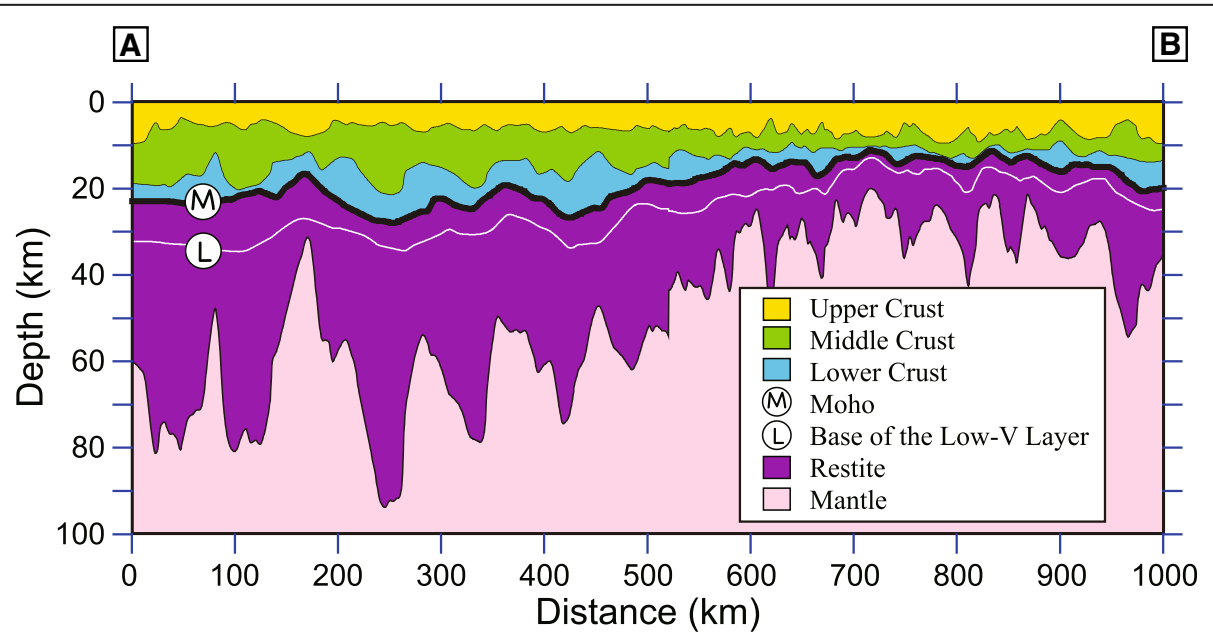

Fig. 6 Depths to the base of the upper, middle, and lower crusts and the inferred restite layer along an arc-parallel section of the IBM (shown in Fig. 2) based on the seismic data of Kodaira et al. (2007a) and the model presented here. They require a restite layer that is much thicker than the low-V uppermost mantle layer, suggesting that most of the restite has delaminated 
unique to the Earth. On other terrestrial planets, the crust is entirely basaltic. Andesitic magmatism and continent crust-forming processes are caused by the subduction of oceanic plates, i.e., the operation of plate tectonics. Plate tectonics was initiated by the foundering of a surface plate along a large crack or fault within a plate, which could only develop in the presence of liquid water at the surface. Water also plays a key role in the generation of andesitic magma, lowering the solidus temperature of the basaltic crust, causing partial melting of the basaltic crust, and producing differentiated, i.e., rhyolitic to andesitic, magmas.

The basaltic crust has evolved into an andesitic continental crust via the delamination of the $\mathrm{SiO}_{2}$-deficient and dense anti-continent that was created complementary to the continental crust from the initial basaltic crust. The Earth has been simultaneously creating continents at the top of the mantle and the anti-continent at the base of the mantle, and consequently has evolved into a unique planet.

\section{Competing interests}

The authors declare that they have no competing interests.

\section{Authors' contributions}

All authors participated in the design of the study and data analysis. All authors read and approved the final manuscript.

\section{Acknowledgements}

We would like to thank Toshihiro Suzuki and Koji Shukuno for productive discussions and Alex Nicholls, editor Toshi Yamazaki, and two anonymous reviewers for their constructive comments on the manuscript.

\section{Author details}

'Department of Planetology, Kobe University, Kobe 6567-8501, Japan. ${ }^{2}$ Research and Development Center for Ocean Drilling Science, Japan Agency for Marine-Earth Science and Technology, Yokosuka 237-0061, Japan. ${ }^{3}$ Research and Development Center for Earthquake and Tsunami, Japan Agency for Marine-Earth Science and Technology, Yokohama 236-0001, Japan.

Received: 2 February 2015 Accepted: 9 June 2015

Published online: 17 June 2015

\section{References}

Aitta A (2012) Venus' internal structure, temperature and core composition. Icarus 218:967-974

Albarède F (1998) The growth of continental crust. Tectonophys 296:1-14 Behn MD, Kelemen PB (2006) Stability of arc lower crust: insights from the Talkeetna arc section, south central Alaska, and the seismic structure of modern arcs. J Geophys Res 111: doi:10.1029/2006JB004327

Christensen NI, Mooney WD (1995) Seismic velocity structure and composition of the continental crust: a global view. J Geophys Res 100:9761-9788

Clift P, Vannucchi P (2004) Controls on tectonic accretion versus erosion in subduction zones: implications for the origin and recycling of the continental crust, Rev Geophys 42: doi: 10.1029/2003RG000127

Coleman RG (1977) Ophiolites. Springer Verlag, New York, p 220

Connolly JAD (1990) Multivariable phase-diagrams—an algorithm based on generalized thermodynamics. Am J Sci 290:666-718

Connolly JAD (2005) Computation of phase equilibria by linear programming: a tool for geodynamic modeling and its application to subduction zone decarbonation. Earth Planet Sci Lett 236:524-541

Crawford WC, Hildebrand JA, Dorman LM, Webb SC, Wiens DA (2003) Tonga Ridge and Lau Basin crustal structure from seismic refraction data. J Geophys Res 108:2195. doi:10.1029/2001JB001435
Dewey JF, Bird JM (1971) Origin and emplacement of the ophiolite suite: Appalachian ophiolites in Newfoundland. J Geophys Res 76:3179-3206

Dilek Y, Furnes H (2011) Ophiolite genesis and global tectonics: geochemical and tectonic fingerprinting of ancient oceanic lithosphere. Geol Soc Am Bull 123:387-411

England P, Houseman G (1989) Extension during continental convergence, with application to the Tibetan plateau. J Geophys Res 94:17561-17579

Ewart A (1982) The mineralogy and petrology of Tertiary-Recent orogenic volcanic rocks: with special reference to the andesitic-basaltic compositional range. In: Thorp RS (ed) Andesites: orogenic andesites and related rocks. John Wiley and Sons, New York, pp 25-95

Gill JB (1981) Orogenic andesites and plate tectonics. Springer, Berlin

Hacker BR, Abers GA, Peacock SM (2003) Subduction factory; 1, theoretical mineralogy, densities, seismic wave speeds, and $\mathrm{H} 2 \mathrm{O}$ contents. J Geophys Res 108: doi:10.1029/2001JB001127

Hopkins MD, Harrison TM, Manning CE (2010) Constrains on Hadean geodynamics from mineral inclusions in $>4$ Ga zircons. Earth Planet Sci Lett 298:367-376

Ishii T, Sato H, Haraguchi S, Fryer P, Fujioka K, Bloomer SH, Yokose H (2000) Petrological characteristics of peridotites from serpentinite seamounts in the Izu-Ogasawara-Mariana Forearc. J Geogra 109:517-530

Ishizuka O, Uto K, Yuasa M, Hochstaedter AG (2002) Volcanism in the earliest stage of back-arc rifting in the Izu-Bonin Arc revealed by laser-heating ${ }^{40} \mathrm{Ar}{ }^{39} \mathrm{Ar}$ dating. J Volcanol Geotherm Res 120:71-85

Ishizuka O, Tani K, Reagan MK, Kanayama K, Umino S, Harigane Y, Sakamoto I, Miyajima Y, Yuasa M, Dunkley DJ (2011) The timescales of subduction initiation and subsequent evolution of an oceanic island arc. Earth Planet Sci Lett 306:229-240

Jull M, Kelemen PB (2001) On the conditions for lower crustal convective instability. J Geophys Res 106:6423-6446

Karato S, Wu P (1993) Rheology of the upper mantle: a synthesis. Science 260:771-778

Kawate S, Arima M (1998) Petrogenesis of the Tanzawa plutonic complex, central Japan: exposed felsic middle crust of the Izu-Bonin-Mariana arc. Island Arc 7:342-358

Kay RW, Kay SM (1993) Delamination and delamination magmatism. Tectonophys 219:177-189

Kelemen PB (1995) Genesis of high Mg-andesites and the continental crust. Contrib Mineral Petrol 120:1-19

Kodaira S, Sato T, Takahashi N, Ito A, Tamura Y, Tatsumi Y, Kaneda Y (2007a) Seismological evidence for variable growth of crust along the Izu intra-oceanic arc. J Geophys Res 112:B05104. doi:10.1029/2006JB004593

Kodaira S, Sato T, Takahashi N, Miura S, Tamura Y, Tatsumi Y, Kaneda Y (2007b) New seismological constraints on growth of continental crust in the Izu-Bonin intra-oceanic arc. Geology 35:1031-1034

Komiya T, Maruyama S, Masuda T, Nohda S, Hayashi M, Okamoto K (1999) Plate tectonics at 3.8-3.7 Ga: field evidence from the Isua accretionary complex southern West Greenland. J Geol 107:515-554

Korenaga J (2009) Scaling of stagnant-lid convection with Arrhenius rheology and the effects of mantle melting. Geophys J Int 179:154-170

Meijer A (1980) Primitive arc volcanism and a boninite series: Examples from western Pacific island arcs. In: Hayes DE (ed) The tectonic evolution of Southeast Asian seas and islands, vol 23, American Geophysical Union Monograph. AGU, Washington, pp 269-282

Moresi L, Solomatov V (1998) Mantle convection with a brittle lithosphere: thoughts on the global tectonic styles of the Earth and Venus. Geophys J Int 133:669-682

Nakanishi A, Kurashimo E, Tatsumi Y, Yamaguchi H, Miura S, Kodaira S, Obana K, Takahashi N, Tsuru T, Kaneda Y, Kawasaki T, Hirata N (2009) Crustal evolution of the southwestern Kuril arc, Hokkaido, Japan, deduced from seismic velocity and geochemical structure. Tectonophys 472:105-123

Nutman AP, Friend CRL, Bennett VC (2002) Evidence for 3650-3600 Ma assembly of the northern end of the Itsaq Gneiss Complex, Greenland: implication for early Archean tectonics. Tectonics 21:1-28

Rudnick RL (1995) Making continental crust. Nature 378:571-578

Sakamoto I, Hirata D, Fujioka K (1999) Description of basement rocks from the Izu-Bonin arc. Res Rep Kanagawa Pref Mu 9:21-39

Sato T, Kodaira S, Takahashi N, Tatsumi Y, Kaneda Y (2009) Amplitude modeling of the seismic reflectors in the crust-mantle transition layer beneath the volcanic front along the northern Izu-Bonin island arc. Geochem Geophys Geosys 10: doi:10.1029/2008GC001990 
Schubert G, Turcotte DL, Olson P (2001) Mantle convection in the earth and planets. Cambridge Univ Press, Cambridge

Shirey SB, Kamber BS, Whitehouse MJ, Mueller PA, Basu AR (2008) A review of the isotopic and trace element evidence for mantle and crustal processes in the Hadean and Archean: implications for the onset of plate tectonic subduction. Geol Soc Am Special Paper 440:1-29

Smith DE, Zuber MT, Phillips RJ, Solomon SC, Hauck SA II, Lemoine FG, Mazarico E, Neumann GA, Peale SJ, Margot JL, Johnson CL, Torrence MH, Perry ME, Rowlands DD, Geossens S, Head JW, Taylor AH (2012) Gravity field and internal structure of Mercury from NESSENGER. Science 336:214-217

Solomatov VS (1995) Scaling of temperature- and stress-dependent viscosity convection. Phys Fluids 7:266-274

Stern RJ (2005) Evidence from ophiolites, blueschists, and ultrahigh-pressure metamorphic terranes that the modern episode of subduction tectonics began in Neoproterozoic time. Geology 33:557-560

Stern RJ, Tamura Y, Ishizuka O, Shukano H, Bloomer SH, Embley RW, Leybourne M, Kawabata H, Nunokawa A, Nichols AL, Kohut E, Pujana I (2013) Volcanoes of the Diamante Cross-Chain: evidence for a mid-crustal felsic magma body beneath the southern Izu-Bonin-Mariana arc. In: Tuena A et al. (eds) Orogenic andesites and crustal growth, Geol Soc London Spec Pub 385:235-255

Stevenson DJ (2001) Mars' core and magnetism. Nature 412:214-219

Suyehiro K, Takahashi N, Ariie Y, Yokoi Y, Hino R, Shinohara M, Kanazawa T, Hirata N, Tokuyama H, Taira A (1996) Continental crust, crustal underplating, and low-Q upper mantle beneath an oceanic island arc. Science 272:390-392

Takahashi N, Kodaira S, Klemperer LS, Tatsumi Y, Kaneda Y, Suyehiro K (2007) Crustal structure and evolution of the Mariana intra-oceanic island arc. Geology 35:203-206

Takahashi N, Kodaira S, Tatsumi Y, Kaneda Y, Suyehiro K (2008) Structure and growth of the Izu-Bonin-Mariana arc crust: I. Seismic constraint on crust and mantle structure of the Mariana arc-back-arc system. J Geophys Res 113:B01104. doi:10.1029/2007JB005120

Tamura Y, Gill JB, Tollstrup D, Hawabata H, Shukuno H, Chang Q, Miyazaki T, Takahashi T, Hirahara Y, Hodaira S, Ishizuka O, Suzuki T, Kido Y, Fiske RS, Tatsumi Y (2009) Silicic magmas in the Izu-Bonin oceanic arc and implications for crustal evolution. J Petrol 50:685-723

Tani K, Dunkley DJ, Kimura J-I, Wysoczanski RJ, Yamada K, Tatsumi Y (2010) Syncollisional rapid granitic magma formation in an arc-arc collision zone: evidence from the Tanzawa plutonic complex, Japan. Geology 38:215-218

Tatsumi Y (2000) Continental crust formation by crustal delamination in subduction zones and complementary accumulation of the enriched mantle I component in the mantle. Geochem Geophys Geosys 1, doi : 10.1029/2000GC000094

Tatsumi Y (2006) High-Mg andesites in the Setouchi volcanic belt, southwestern Japan: analogy to Archean magmatism and continental crust formation? Ann Rev Earth Planet Sci 34:467-499

Tatsumi Y, Eggins S (1995) Subduction zone magmatism. Wiley, Boston

Tatsumi Y, Suzuki T (2009) Tholeiitic vs. calc-alkalic differentiation and evolution of arc crust: constraints from melting experiments on a basalt from the Izu-Bonin-Mariana arc. J Petrol 50:1575-1603

Tatsumi Y, Sakuyama M, Fukuyama H, Kushiro I (1983) Generation of arc basalt magmas and thermal structure of the mantle wedge in subduction zones. J Geophys Res B88:5815-5825

Tatsumi Y, Shukuno H, Tani K, Takahashi N, Kodaira S, Kogiso T (2008) Structure and growth of the Izu-Bonin-Mariana arc crust: 2. Role of crust-mantle transformation and the transparent Moho in arc crust evolution. J Geophys Res: 113, doi:10.1029/2007JB005121

Tatsumi Y, Suzuki T, Ozawa H, Hirose K, Hanyu T, Ohishi Y (2014) Accumulation of 'anti-continent' at the base of the mantle and its recycling in mantle plumes. Geochim Cosmochim Acta 143:23-33

Taylor B (1992) Rifting and the volcanic-tectonic evolution of the Izu-Bonin-Mariana arc system. In: Taylor B. et al. (eds) Proceedings of ocean drilling program, scientific results, Texas A\&M Univ., College Station 126: 627-650

Taylor SR (1967) The origin and growth of continents. Tectonophys 4:17-34

Taylor SR, McLennan SM (1995) The geochemical evolution of the continental crust. Rev Geophys 33:241-265

Taylor SR, McLennan SM (2009) Planetary crusts: their composition, origin and evolution. Cambridge Univ Press, Cambridge

Turcotte DL (1989) Geophysical processes influencing the lower continental crust. In: Mereu RF, Mueller S, Fountain DM (eds) Properties and processes of Earth's lower crust. Am Geophys Union, Washington, pp 321-329

Valencia D, Sasselov DD, O'Connell RJ (2007) Radius and structure models of the first super-Earth planet. Astrophys I 656:545-551

\section{Submit your manuscript to a SpringerOpen ${ }^{\odot}$ journal and benefit from:}

- Convenient online submission

- Rigorous peer review

- Immediate publication on acceptance

- Open access: articles freely available online

- High visibility within the field

- Retaining the copyright to your article

Submit your next manuscript at $>$ springeropen.com 